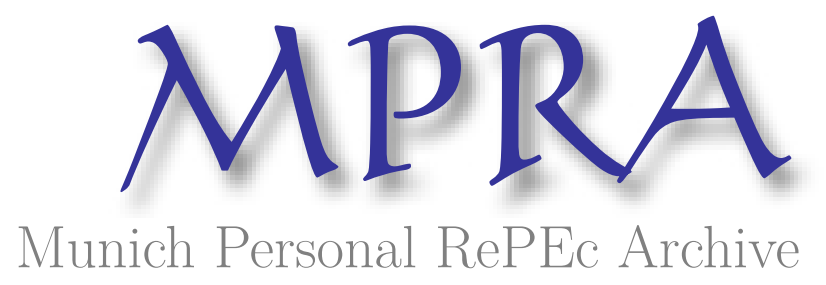

\title{
IFRSs for financial instruments, quality of information and capital market's volatility: an empirical assessment for Eurozone
}

Cuzman, Ioan and Dima, Bogdan and Dima (Cristea), Stefana Maria

2010

Online at https://mpra.ub.uni-muenchen.de/27167/

MPRA Paper No. 27167, posted 06 Dec 2010 10:18 UTC 


\title{
IFRSS FOR FINANCIAL INSTRUMENTS, QUALITY OF INFORMATION AND CAPITAL MARKET'S VOLATILITY: AN EMPIRICAL ASSESSMENT FOR EUROZONE
}

\author{
Ioan CUZMAN, PhD Professor \\ Vasile Goldiş Western University of Arad \\ Faculty of Economic Sciences \\ Address: 15, Mihai Eminescu St., Arad, Romania \\ Tel: +40 257213066 \\ Email address: cuzman@sif1.ro \\ Bogdan DIMA, PhD Professor \\ West University of Timişoara, Faculty of Economics \\ Address: 16, H. Pestalozzi St., Timișoara, Romania \\ Tel: +40 256592505 \\ Email address: bogdandima2001@gmail.com \\ Ştefana DIMA (CRISTEA), PhD Lecturer \\ Vasile Goldiş Western University of Arad \\ Faculty of Economic Sciences \\ Address: 15, Mihai Eminescu St., Arad, Romania \\ Tel: +40257213066 \\ Email address: stefana_cristea@yahoo.it
}

\begin{abstract}
This study examines the Eurozone stock markets' reaction to a number of events associated with the post-implementation amendments of the IFRSs regarding financial instruments (IFRS 7, IFRS 9, IAS 32 and IAS 39). The adoption of these IFRSs is probably one of the most important recent changes in financial information environment. However, in order to contribute to an increase in financial stability, it is necessary to ensure an ex post stability of the regulatory framework. Based on this meta-argument, we have analyzed the interlinkages between the episodes of higher market volatility and the amendments to the mentioned IFRSs, inside a binary dependent variable model. Overall, our findings suggest that the adoption of the IFRS can lead to a stabilization of European financial markets but this result is not necessary a robust one since investors prefer a higher stability on standards' contents and application conditions.
\end{abstract}

\section{KEY WORDS}

IFRS 9, IFRS 7, IAS 32, IAS 39, volatility, event study 


\section{INTRODUCTION}

The purpose of this study is to examine the reaction of the European financial markets to the adoption in 2005 of International Financial Reporting Standards (IASs/ IFRSs) by European Union's listed companies and, in particular, to the subsequent amendments of the standards regarding financial instruments (IFRS 7, IAS 32 and IAS 39 and the newly issued IFRS 9). Since, prior this date, most European issuers of financial assets applied domestic standards, this can be viewed as one of the most important recent changes in the informational environment.

One of the key aspects in the analysis of the induced consequences is concerning the stability of the new regulatory framework. At a conceptual level, it could be argued that once the investors are setting a certain "optimal" structure of their financial assets' portfolio, they are tending to preserve - especially in the case of "long term" investment strategies - this structure in order to minimize the structural adjustment costs. But, if the contents of the relevant financial information or its disclosure are changed, then the investors are forced to reexamine the decisional information and to reformulate their individual portfolio's structure optimization problems. Thus, it can be argued that an increased instability of the regulatory framework will lead to higher market volatility and to a greater incertitude in regard to the fundamental determinants of financial assets' price dynamics. In other words, if the benefits of an uniform financial reporting exceed the costs of its adoption - in terms of lowering the costs of comparing firms' financial position and enhanced economic and financial performance due to a better quality of the information used in the decision-making process - , the ex post instability of this framework could diminish such advantages by an increase in the expectations' uncertainty and biased appraisal of the "fundamentals" in financial assets' valuation.

At present, the set of IASs/IFRSs issued by International Accounting Standard Board (IASB) includes 4 standards regarding disclosure, presentation, classification, recognition and valuation of financial instruments as follows:

- IAS 32 Financial Instruments: Presentation;

- IAS 39 Financial Instruments: Recognition and Measurement;

- IFRS 7 Financial Instruments: Disclosures;

- IFRS 9 Financial Instruments: Classification and Measurement.

In April 2009, IASB had decided to undertake a three-stage modification of IAS 39 to be completed in one year:

a) Classification and Measurement of Financial Instruments: this first stage has closed on financial assets with the consultative due process of September 2009 and was followed on November, 12 by the issuance of IFRS 9, which will replace IAS 39 from 2013, with early adoption permitted starting in 2009. In respect to financial liabilities, an exposure draft is expected in the second quarter of 2010 (final IFRS expected in the second half of 2010);

b) Impairment and Provisioning: the IASB issued an exposure draft on impairment in October 2009 (Final IFRS expected on the fourth quarter of 2010);

c) Hedge Accounting: IASB is expected to issue an exposure draft in the second quarter of 2010 (final IFRS expected in the fourth quarter of 2010 or the first quarter of 2011). 
The general idea was that stakeholders, including investors, consider indispensable the revision of IAS 39 (Papa, 2010). Since FASB issued Staff Positions regarding fair value measurement and impairment, IASB had to speed up the process it started on April, $1^{\text {st }}, 2009$. The FASB is expected to issue a single exposure draft in early 2010 , covering all the key aspects of financial instrument accounting. The G20' summit participants in London pleaded on standard-setters "to reduce the complexity of accounting standards for financial instruments"i. Basel Committee agreed that costbased accounting is appropriate for some categories of financial instruments. The due process on the topic included: more then two hundreds comments from individuals and organizations; meetings with investors, regulators, prudential supervisors held all around the world; additional board meetings.

In European Union, EFRAG had posted on its website an Invitation to Comment on its EFRAG draft endorsement advice in regard to IFRS 9 endorsement in EU ${ }^{\mathrm{ii}}$. After assessing the costs and benefits that this standard implementation might have, in the respective draft EFRAG stated that endorsement would lead to reliable and comparable information. However, both EFRAG and ARC postponed the decision on IFRS 9 implementation arguing that "more time should be taken to consider the output from the IASB project to improve accounting for financial instruments. [...] EFRAG is currently considering how it will proceed in its work to address the package of standards that are expected to replace IAS 39"iii IASB attempted to reply to the European Commission expressed concerns, such as that the standard would have resulted in expanded application of fair value accounting, in particular when it is not the most decision useful measurement basis. The EU has linked this issue to the G20's and ECOFIN Council's objective to ensure that accounting standards do not undermine financial stability while improving decision making process.

Thus, the issuance of IFRS 9 caused a dispute that tested the boundaries of current EC and IASB relationship. An exchange of official letters was carried out and this situation has begun to have a negative on European investors' perception of recent changes in the field of financial instruments. Even some Member States started to show some discomfort with IFRS 9 based on country particularities. In order to calm things down, the European Commissioner McCreevy stated on 19.11.2009 that "The European Commission remains fully committed to IFRS as the single set of globally accepted accounting standards. Moreover, EU stakeholders unanimously support the general approach based on a mixed attribute measurement model used by the IASB in IFRS 9. The decision not to seek accelerated endorsement of IFRS 9 at this stage reflects the changed economic outlook and market improvements"iv ${ }^{\text {iv }}$ The Commission will continue to assess all the aspects of the new standards, remaining for the next college of Commissioners to take a final decision in regard to this.

The problem that remains is whether the changes in international standards improve decision-usefulness and reduce the complexity of financial instrument accounting. The Chartered Financial Analysts recently conducted a global membership survey (CFA Institute, 2009). The survey was administered after IFRS 9 was issued, during the two week period between November 16th and December 1st, 2009. The survey feedback is expected to be useful to both the IASB and the US Financial Accounting Standards Board (FASB), as they continue to update their financial instrument accounting standards over the coming months, and possibly come up with a converged solution, as this has been described as a joint project. The respondent geographic profile was as follows: $55 \%$ from the Americas, $28 \%$ from Europe, 
Middle East, Africa (EMEA), and 14\% from Asia Pacific (APAC). The occupational profile was: $25 \%$ research analysts, $23 \%$ portfolio managers, $12 \%$ corporate financial analysts and $19 \%$ accountants/auditors.

The overall results show that, on balance, there is a perception of some improvement in the decision usefulness. This is demonstrated by a higher proportion of respondents answering that the standard improves decision usefulness and reduces complexity, relative to those who think it does not. The results show that $47 \%$ of respondents think the standard improved decision-usefulness, while $22 \%$ think it did not and $31 \%$ are neutral. It also showed $37 \%$ think the model reduced complexity, while $28 \%$ think it did not and $35 \%$ are neutral. Therefore, there is no unanimous perception of improvement or effectiveness in reducing complexity by this new standard.

Another key conclusion is that there may be room for more to be done on financial instrument accounting, despite the incremental perceived improvements having been achieved through IFRS 9. IFRS 9 is premised on the mixed measurement attribute approach. When asked which measurement approach could best improve financial instrument accounting; only $33 \%$ of respondents selected the mixed measurement attribute of either fair value or amortized cost for financial instrument. On the other hand, $60 \%$ selected some variant of full fair value for financial instruments (i.e. $40 \%$ selected full fair value, with amortized cost in the notes, and $20 \%$ selected both amortized cost and full fair value in financial statements with separate presentation). From this finding, it can also be inferred that $53 \%$ prefer the retention of some form of amortized cost (i.e. the $33 \%$ who favor the mixed attribute and the $20 \%$ that selected both the presentation of both amortized cost and fair value). Either way, the results show that respondents would view the need for greater levels of fair value for all financial instruments than is achieved through a mixed measurement attribute approach.

The conclusion of the support for greater level of fair value application for financial instruments is further backed by the marginally higher proportion of respondents who think the prospective FASB model is better (40\%). This proportion exceeded those who think it is worse $(31 \%)$ while $9 \%$ see no difference and $21 \%$ are not sure. The FASB model is understood as intending to have fair value for most financial instruments on the balance sheet.

The preference for the prospective FASB model was consistent across key geographic regions. However, the preference is strongest from Americas and weakest from APAC. The preference is consistently higher among the more user oriented segment of respondents (i.e. the corporate financial analysts, portfolio managers and research analysts) relative to accountants/auditors who slightly seem to prefer the IASB model.

On the other hand, looking at the information provided on the treatment of financial assets and liabilities, CESR (2009) has analyzed 96 European listed banks and/or insurers, including 22 companies from the FTSE 100 index. More reasons for such studies considering that the financial crisis has had a major impact on the financial position and performance of publicly traded companies. Thus, CESR performed an analysis of how the detailed requirements of IFRS 7 and certain related guidance had been applied.

The results of this analysis show that "in some areas a significant proportion of European financial companies failed to comply with mandatory disclosure requirements relating to financial instruments". CESR believes that this information is key to understand a company's financial position and performance and that its omission could consequently affect the ability of investors to make decisions 
regarding their investment. CESR would have expected a higher level of compliance with mandatory requirements, particularly in light of the market conditions that existed during the second half of 2008 and the beginning of 2009. At the same time, CESR notes that a significant number of companies provided additional disclosures in line with the recommendations that were published in late 2008, which is to be welcomed. CESR found a good level of compliance with disclosure requirements on the classification of financial assets and liabilities and their carrying amounts under IFRS 7. Many entities enhanced their fair value disclosures on certain instruments they believed to be of importance for users and provided additional information to help users to better understand the financial statements.

However, examples of noncompliance included: disclosures about the use of valuation techniques and relationships with special purpose entities (SPEs). In regard to the second aspect, the analysis showed that around $40 \%$ of the companies analyzed did not have any SPEs. Of the rest, around $20 \%$ of all companies did not disclose details of how they had exercised their judgment on whether the substance of the relationship between the entity and a SPE indicated that the SPE is controlled by that entity. A smaller proportion of FTSE 100 companies did not provide these disclosures compared to the sample as a whole. In addition, around $20 \%$ of the companies having SPEs did not disclose details of how they had exercised their judgment in deciding when all the significant risks and rewards of ownership of financial assets had been transferred to other entities.

Other research studies (for instance Armstrong et al., 2008) examined the market reactions to the introduction of IFRSs previous to the crisis and concluded that there was a positive corporate reaction especially for companies with lower quality preadoption financial information, whereas less attention was paid until now to the effects of subsequent modifications of these standards. These amendments were made under the impact of the discussions concerning IFRSs' costs and benefits and the difference between EU and other economic areas that require or permit the use of IFRSs.

In this context, we have examined the recent evolutions of European capital markets and tried to find the interlinkages of those with different events in IFRSs' modification process. For these reasons, Section 1 present an analytical framework build around the impact of information quality on financial assets' prices and an evaluation of IFRSs' impact on this quality according to investors requirements. Section 2 describes the data and the research design, while Section 3 provides the results of the advanced empirical analysis. Several conclusions are drawn and further research directions are indicated in last section of the paper. The main output of the paper consists in the thesis that there is a certain connection between the frequency in IFRSs' modification and the market volatility. Consequently, the stability of the regulatory framework matters in assessing the financial stability.

\section{INFORMATION QUALITY AND PRICES' VOLATILITY}

The prices mechanisms are significantly influenced by the characteristics of the information that is implied by the trade of financial assets, since sophisticated institutional market makers as well as individual investors are requiring a significant amount of information as decisional support for the optimization of their portfolios' 
structures. From this point of view, these assets can be seen as highly entropic ones. The adoption of IFRSs substantially changes the informational architecture of markets allowing a redesign of the decisional tools and more accurate trading decisions.

Our argumentation can be resumed by the next two basic hypotheses:

H1: The decisions of the investors in financial assets are influenced by the volume, structure and quality of the corresponding information that underlines the issue and the trade of these assets;

H2: The adoption and implementation of IFRSs are substantially changing the informational architecture of the financial markets.

The financial markets are incorporating a large volume of information concerning the various signals affecting the specific prices' mechanisms. This information concerns both the fundamental aspects linked to the financial position and economic performance of the issuers as well as the different endogenous and exogenous informational shocks generated by the changes in the market conditions and by the sectors or global economic environment. The investors' reaction to the newly available information is influenced by this information's nature and by their a priori anticipation mechanisms and confidence in the quality of information. Following an approach proposed by Epstein and Schneider (2008), we consider that the investors' behavior can be described by recursive multiple-priors utility functions (they behave as if they are maximizing, every successive period, the expected utility under a worstcase belief chosen from a set of conditional probabilities) and that they have asymmetric responses to the imperfect information situations. More exactly, it is supposed that there is an informational leverage effect - bad news affect conditional actions with implication on portfolio structures more than good news.

Another key assumption is the presumption of both short and long term learning mechanisms: when the investors have reliable information, they are able to learn from past data as well as from the current acquired information and to form their anticipations within a safety confidence interval.

Correlatively, when the quality of information is poor, the investors are treating the informational signals as ambiguous and tend to adjust in negative sense their expectations. Thus, the prices' formation is driven by a combination of previous informational shocks and current distribution of information. Formally:

$$
\begin{aligned}
& P_{t}=\theta\left(I_{t}\right)+h\left(\sum_{i=t-k}^{t-1} \varepsilon_{i}\right)+\varepsilon_{t} \\
& (\forall) \varepsilon_{i} \approx N\left(0, \sigma_{s}^{2}\right), \sigma_{s}^{2} \in\left[\sigma_{-s}^{2}, \sigma_{s}^{2}\right]
\end{aligned}
$$

Here the prices $P$ of the current period $t$ are determined by a signal parameter $\theta$ which depends on an informational index $I$ designed to capture the entire information found on market from past and current periods, $\varepsilon_{i, i=t-k \ldots t}$ are idiosyncratic shocks and $h$ is the learning function depending on the past forecasting errors; while $\alpha, \beta$ are weighting parameters reflecting the relative importance of core and shocks' components of the anticipation mechanisms.

Thus, the prices' deviations from their main tendencies, $r_{t}$ (global volatility) can be expresses as a function of changes in the informational structure of the market (intrinsic volatility) and of various past cumulative and present shocks (transitory volatility) like: 


$$
r_{t}=z\left(\frac{\partial \theta}{\partial I}, \frac{\partial h}{\partial t}, \mu\left(\varepsilon_{t}\right)\right)
$$

In this framework, the adoption of IFRSs can exercise various influences especially on the intrinsic component of volatility. In greater details, it can be argued that $I$ reflects mainly the fundamental information about the issuers (together with the main features of the market) and this information is sensitive to the principles of its design and distribution. Thus, $I_{t}=\omega\left(I_{t}^{\prime}\right)$ with $I^{\prime}$ being the financial information component of $I$. As a consequence, the changes both in the structure and in the displayed form of the financial information will determine corresponding adjustments in the prices' volatility. It must be noticed that such effects are exercised not only by the current, but also by the anticipated shifts in the contents of financial statements: the investors who predict the emergence of some new significant information, will adjust their present investment plans according to its expected contents. A key issue in this transmission mechanism is the quality of the current and forecasted information. As the quality of information decrease, its noise component tends to increase as well its ambiguity. As Epstein and Schneider (2008: 198) argue "In markets with ambiguous information, expected excess returns decrease with future information quality. Indeed, ambiguity-averse investors require compensation for holding an asset simply because low quality information about that asset is expected to arrive". But the quality of the information cannot be judged per se since the baseline for evaluating this quality should consists in the specific needs of investors. If such an argument holds, than the analysis task is to evaluate the potential impact of IFRSs on information's quality according to the specific investors' requirements.

Table 1: Investors' requirements for financial information and their compliance with IFRSs

\begin{tabular}{||l|l|c|l||}
\hline REQUIREMENT & MOTIVATION & COMPLIANCE & EXPLANATION \\
\hline $\begin{array}{l}\text { 1.Transparency, } \\
\text { recuracy and }\end{array}$ & $\begin{array}{l}\text { For well informed } \\
\text { investment } \\
\text { decisions }\end{array}$ & + & $\begin{array}{l}\text { The entire set of } \\
\text { standards is build } \\
\text { around providing } \\
\text { transparent and } \\
\text { reliable information to } \\
\text { investors and creditors }\end{array}$ \\
\hline 2. Stability & $\begin{array}{l}\text { For long term } \\
\text { investment } \\
\text { decisions }\end{array}$ & $\begin{array}{l}\text { Work in progress; a } \\
\text { framework still } \\
\text { changed }\end{array}$ \\
\hline 3. Uniformity & $\begin{array}{l}\text { For inter-issuers } \\
\text { and financial } \\
\text { instruments } \\
\text { comparative } \\
\text { purposes }\end{array}$ & $+/-$ & $\begin{array}{l}\text { Different local } \\
\text { interpretations of } \\
\text { standards }\end{array}$ \\
\hline 4. Relevance & $\begin{array}{l}\text { For a sound } \\
\text { analysis of the } \\
\text { issuers' economic } \\
\text { and financial } \\
\text { performances }\end{array}$ & + & $\begin{array}{l}\text { Highly relevant } \\
\text { especially for cross- } \\
\text { border transactions of } \\
\text { transnational } \\
\text { corporations and } \\
\text { international investors }\end{array}$ \\
\hline
\end{tabular}




\begin{tabular}{||l|l|c|l||}
\hline 5. Concision & $\begin{array}{l}\text { For helping in the } \\
\text { selection of the } \\
\text { relevant analysis' } \\
\text { features }\end{array}$ & + & $\begin{array}{l}\text { Principles based } \\
\text { system }\end{array}$ \\
\hline 6. Specialization & $\begin{array}{l}\text { For a more oriented } \\
\text { information } \\
\text { distribution } \\
\text { according to the } \\
\text { investors' specific } \\
\text { needs }\end{array}$ & - & $\begin{array}{l}\text { With some exceptions, } \\
\text { general principles } \\
\text { system }\end{array}$ \\
\hline $\begin{array}{l}\text { 7. Cost / output } \\
\text { balanced }\end{array}$ & $\begin{array}{l}\text { For minimizing the } \\
\text { informational costs }\end{array}$ & - & $\begin{array}{l}\text { First-time adoption } \\
\text { costs highly depend on } \\
\text { size, location or } \\
\text { jurisdiction }\end{array}$ \\
\hline
\end{tabular}

From the Table 1, it looks like the impact of IFRSs implementation is rather an ambiguous one, since at least some of these requirements are met by the standards while for others the compliance seems to be less clear. Of course, the requirements cannot be seen as equiponderate in the evaluation of information's characteristics and, for instance, a higher level of transparency can compensate a greater cost of first time implementation. However, the IFRSs are designed to increase the quality of financial reporting and despite their limits the standards can improve the capacity of investors to capture the informational signals relevant for forecasting the fundamentals.

Thus, by combining $H 1$ and $H 2$ our research hypothesis can be formulated as:

$\mathbf{H}$ : The adoption of IFRS can, in certain conditions, contribute to a decrease in financial markets' volatility but, in the current stage, this effect is not necessary a robust one.

\section{DATA AND RESEARCH DESIGN}

Even if the creation of the Eurozone boosted up the financial unification process in Europe, a single integrated financial system in this area is a distant dream. There are significant differences between the Member States in the Eurozone and the rest of the European Union's countries - especially, the new emergent economies.

For these, the financial infrastructure does not reach yet the "critical point" being incompletely linked to the EU's 13 markets. Due to this reason, in order to avoid the structural distortions' consequences on the financial stability and to provide some empirical evidences to support the $H$ hypothesis, we focus our study only on Eurozone Member States. The status of the developed capital market is captured by a relevant European stock markets' index. The Dow Jones EURO STOXX 50 Index, Europe's leading Blue-chip index for the Eurozone, provides a Blue-chip representation of super sector leaders in the Eurozone. The index covers 50 stocks from 12 Eurozone countries (the Cyprus market is not included in the coverage of the index).

Data represent quarterly average values of the index' close from the first quarter of 2005 to the last quarter of 2009 and are adjusted for seasonally variations with the 
X12-ARIMA procedure and for splits in the index components (http://finance. yahoo.com/q? $=\% 5$ ESTOXX50E).

Table 2 reports the statistics by classification for the close values of the index. It can be noticed that there can be identified in terms of distribution three data sub-groups. The first two, between [3000, 3500) and respectively [3500, 4000), display a long right tail and is more flat (platykurtic) relative to the normal one, while the last subgroup between [4000, 4500) has a long left tail. Such a finding is common for different financial infrastructures and it reflects the various imperfections to affect their efficiency.

Also the index evolution can be described according to Table 2 as a unit root with drift process.

Table 2. Unit root tests for close of Dow Jones EURO STOXX 50 Index (seasonally adjusted)

\begin{tabular}{|c|c|c|c|c|c|}
\hline & NULL & ALTERNATIVE & TEST & CONC & SION \\
\hline $\begin{array}{l}\text { Breitung } \\
\text { non } \\
\text { parametric } \\
\text { test }\end{array}$ & $\begin{array}{l}\text { Unit root with } \\
\text { drift }\end{array}$ & Trend stationarity & 0.022 & $\begin{array}{l}\text { Accept } \\
\text { H0 at } \\
5 \%\end{array}$ & $\begin{array}{l}\text { Accept } \\
\text { H0 at } \\
10 \%\end{array}$ \\
\hline $\begin{array}{l}\text { Phillips- } \\
\text { Perron }\end{array}$ & $\begin{array}{l}\text { Unit root with } \\
\text { drift }\end{array}$ & Trend stationarity & $\begin{array}{l}-2.080 \\
\text { (p-value } \\
=0.97)\end{array}$ & $\begin{array}{l}\text { Accept } \\
\text { H0 at } \\
5 \%\end{array}$ & $\begin{array}{l}\text { Accept } \\
\text { H0 at } \\
10 \%\end{array}$ \\
\hline KPSS & $\begin{array}{c}\text { Trend } \\
\text { stationarity }\end{array}$ & $\begin{array}{l}\text { Unit root with } \\
\text { drift }\end{array}$ & 0.194 & $\begin{array}{l}\text { Reject } \\
\text { H0 at } \\
5 \%\end{array}$ & $\begin{array}{l}\text { Reject } \\
\text { H0 at } \\
10 \%\end{array}$ \\
\hline $\begin{array}{l}\text { Bierens- } \\
\text { Guo (type } \\
\text { I) }\end{array}$ & $\begin{array}{c}\text { Trend } \\
\text { stationarity }\end{array}$ & $\begin{array}{l}\text { Unit root with } \\
\text { drift }\end{array}$ & 4.044 & $\begin{array}{l}\text { Reject } \\
\text { H0 at } \\
5 \%\end{array}$ & $\begin{array}{l}\text { Reject } \\
\text { H0 at } \\
10 \% \\
\end{array}$ \\
\hline $\begin{array}{l}\text { Bierens- } \\
\text { Guo (type } \\
\text { II) }\end{array}$ & $\begin{array}{c}\text { Trend } \\
\text { stationarity }\end{array}$ & $\begin{array}{l}\text { Unit root with } \\
\text { drift }\end{array}$ & 4.485 & $\begin{array}{l}\text { Reject } \\
\text { H0 at } \\
5 \%\end{array}$ & $\begin{array}{l}\text { Reject } \\
\text { H0 at } \\
10 \% \\
\end{array}$ \\
\hline
\end{tabular}

The volatility of the index is derived based on the deviations from the trend component of the close:

$$
\text { Deviation }_{t}=\text { Close }_{t}-\text { Close }_{t}{ }_{t}
$$

Here the trend (plus cycle) component is computed based on X12-ARIMA applied on the seasonally adjusted data. As a further step, a binary variable is constructed in order to capture the quarterly shifts in the volatility according to the next rule:

$$
\text { bin }_{t}= \begin{cases}1 & \text { if } \text { garch }_{t}>\text { garch }_{t-1} \\ 0 & \text { otherwise }\end{cases}
$$

The tabulation of this variable is reported in Table 3. A simple inspection of the values reflects the existence of two relatively distinct areas of volatility dynamics. First, characterized by an upward trend in the index volatility under the pressure of exogenous and endogenous determinants of financial turbulence, is specific for the real and financial instability and turbulence between 2006 and first half of 2008 . 
Table 3. Tabulation of Close $_{\mathbf{t}}-$ Close $_{\mathbf{t}}{ }_{\mathbf{t}}$

\begin{tabular}{|l|l|l|l|l||}
\hline \multicolumn{4}{||l|}{ Included observations: 20; Number of categories: 3} \\
\hline & & & Cumulative & Cumulative \\
\hline Value & Count & Percent & Count & Percent \\
\hline$[-0.05,0)$ & 10 & 50.00 & 10 & 50.00 \\
\hline$[0,0.05)$ & 9 & 45.00 & 19 & 95.00 \\
\hline$[0.05,0.1)$ & 1 & 5.00 & 20 & 100.00 \\
\hline Total & 20 & 100.00 & 20 & 100.00 \\
\hline \hline
\end{tabular}

The last part, between the second part of 2008 and the end of 2009, reflects a slowly stabilization process and a certain tendency for a lower volatility (see Graphic 1).

\section{Graphic 1. The volatility of Dow Jones EURO STOXX 50}

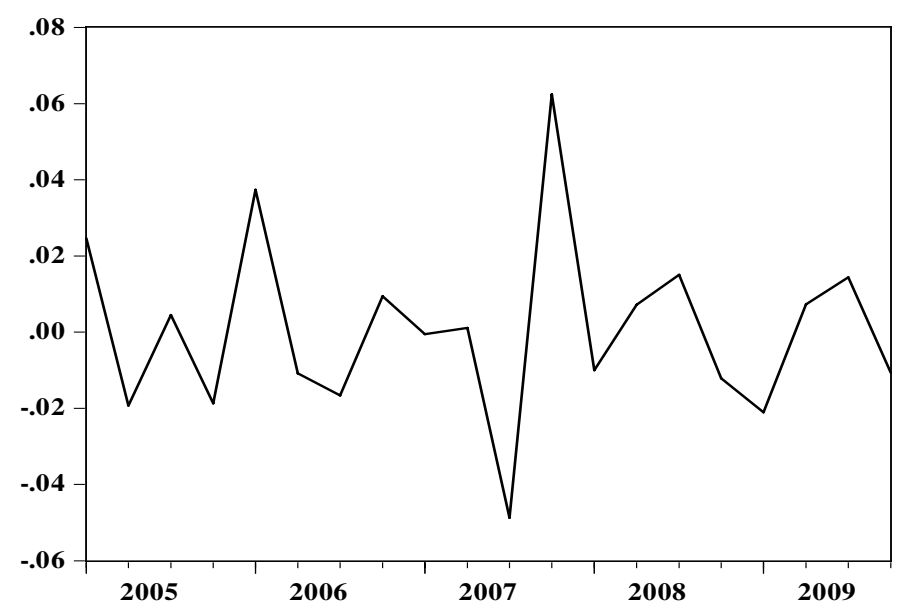

In order to address the issue of the possible inter-linkages between such a descriptive variable and the adoption of the relevant IFRSs, it is necessary to take into account the informational efficiency of the European stock markets. More exactly, it could be argued that there is a two-way connection between the qualitative characteristics of the financial information (in this case, quality, feasibility, transparency and credibility) and the allocation efficiency of financial markets. On one hand, accurate financial information "increases the incentive to invest in the stock market and it favors optimal allocation of savings to investment" (Agostino et al., 2008: 3) and, as a result, increases the efficiency of financial resources' distribution and reallocation. On the other hand, the existence of efficient market mechanisms will tend to lead to rapid corrections of information imperfections by putting a higher pressure on the creation of a more accurate informational environment.

Interestingly, there are not many studies about the efficiency of the European markets and their results tend to be, at least, inconclusive, if not contradictory. For instance, Violi (2004: 59) estimates that "Substantial improvements in the efficiency of the European markets for fixed income securities, especially the degree of government and corporate bond market integration have been achieved in the nineties. Such efficiency gains can be largely attributed to the successful unification of monetary policy in Europe". Worthington and Higgs (2003: 13) concludes that "Among the developed markets, only Germany, Ireland, Portugal, Sweden and the United Kingdom satisfy the most stringent random walk criteria with France, Finland, the 
Netherlands, Norway and Spain meeting at least some of the requirements of a strict random walk".

However, a simply random walk (with drift) tests (Table 4) carried out in the form:

$$
\begin{aligned}
& p_{t}=\alpha+p_{t-1}+\varepsilon_{t} \\
& E\left(\varepsilon_{t}\right)=0, E\left(\varepsilon_{t} \varepsilon_{t-g}\right)=0, g \neq 0
\end{aligned}
$$

and a Brock, Dechert, Scheinkman portmanteau test for time dependence in the returns $r_{t}=\ln \left(\frac{p_{t}}{p_{t-1}}\right)$ series suggests that, at the level of our data, the null of the existence of a (weak) efficiency form in the Dow Jones EURO STOXX 50 Index is sustainable.

Table 4. The random walk and the BDS portmanteau tests for time based

\begin{tabular}{|c|c|c|c|c|c|c|c|}
\hline \multirow[b]{2}{*}{$\varepsilon_{\mathrm{t}}$} & \multicolumn{2}{|c|}{ Final State } & \multicolumn{2}{|c|}{ Root MSE } & \multicolumn{2}{|c|}{ z-Statistic } & Probability \\
\hline & \multicolumn{2}{|c|}{12.177} & & 1.452 & & 8.388 & 0.000 \\
\hline Dimension & $\begin{array}{c}\text { BDS } \\
\text { Statistic }\end{array}$ & Std & Error & z-Sta & & $\begin{array}{c}\text { Normal } \\
\text { Prob. }\end{array}$ & $\begin{array}{c}\text { Bootstrap } \\
\text { Prob. }\end{array}$ \\
\hline 2 & 0.003076 & & 3885 & 0.791 & & 0.4285 & 0.7258 \\
\hline 3 & -0.015164 & & 8402 & -1.80 & & 0.0711 & 0.8412 \\
\hline 4 & 0.005366 & & 3623 & 0.393 & & 0.6937 & 0.7744 \\
\hline 5 & 0.025088 & & 9363 & 1.295 & & 0.1951 & 0.6352 \\
\hline 6 & -0.114504 & & 5513 & -4.488 & & 0.0000 & 0.5004 \\
\hline
\end{tabular}
dependence on Dow Jones EURO STOXX 50 Index

Still, if it is accepted that the market is able to incorporate the financial information and to react according to its changes, it is not clear on an ex ante base whether all the components of this information are equally important for prices' adjustments. Thus, our study is focused only on the effects of the various changes in IFRS 7, IFRS 9, IAS 32 and IAS 39 - concerning disclosure, presentation, recognition and measurement of financial instruments. The implied argument is that especially for passive ("longterm") transaction strategies, these aspects are critical for investor strategies. In other words, we argue that if there is present an "informational leverage" effect, then any change in the status of the objects of financial placements is (with the corresponding adjustment speed) considered (in an asymmetric "good / bad news" manner). Of course, such an approach is not able to emphasize the importance of the financial equilibrium and economic performances of the financial assets' issuers, since it is focused only on these assets.

At this point, it should be noticed that an earlier stage of the literature was founded on an impressive set of theoretical arguments and empirical evidences supporting the thesis of financial information's relevance. However, after the initial enthusiasm, as Dontoh et al. (2000: 1) note: "Recent literature has created a widespread impression that financial statements have lost their value relevance because of a shift from traditional capital-intensive economy into a high technology, service-oriented economy. In particular, it is claimed that financial statements are less relevant in assessing the fundamental value of high-technology, service-oriented firms, which are 
by nature knowledge-intensive". Indeed, there is a large literature that tends to find a decline in the relevance of financial information in the context of global postindustrial economy (for example, Elliott and Jacobsen, 1991; Jenkins, 1994; Sever and Boisclaire, 1990; Ramesh and Thiagarajan, 1995). These studies examine the association between a combination of earnings, change in earnings and book value and contemporaneous stock prices or returns. Another issue discussed by Elliott and Jacobson (1991) and Jenkins (1994) is the increased sophistication of investors, whom in return require more relevant and timely financial and non-financial information to meet their needs.

However, from our point of view, such findings can be overcome, if the different types of learning processes in the investors' decisions are considered. Such processes would be able to guide the adjustments in the construction and management of financial assets' portfolios. If such a process is presumed, then it is possible to take into account more sophisticated interlinkages between the evolution of stocks and the financial performance of their issuers.

A direct testable consequence for such dual interactions is the manifestation of nonlinear connections between prices' dynamics and the contents of financial statements. In this sense, there are recent empirical evidence showing convexity in the relationship between prices and accounting information. Empirical tests, although exploratory, provide further evidence of a nonlinear relation between stock price and accounting valuation methods of earnings and book value (see, for instance, Riffe and Thompson, 1998).

Since the analytical objective of this study is more limited, we will not investigate such types of evidence. The emphasized hypothesis of the present paper is that each event concerning financial assets' standards will be unbiased reflected in their prices under a specific event window.

For the analysis period, we have established a list of such key events in relevant IFRSs' adoption and modification (Appendix 2). A dummy variable codes these events, by counting with a quarterly frequency the situation of reference data and amendments. More exactly, the level of this dummy is represented by the total number of events for a certain quarter (without distinguishing between the three standards). The quarter score is established like the cumulated sum of current and previous quarter's number of events. Our argument, for such an approach, is that the relative importance of each standard cannot be ex ante presumed, so we draw our inference from market reactions' analysis associated with all the events, rather than with the events specific to an individual standard.

The connections between the binary variable and the dummy one are analyzed inside a binary dependent variable model. The presumed distribution of the errors is an extreme value one:

$$
\operatorname{Pr}\left(y_{i}=1 \mid \mathrm{x}_{\mathrm{i}}, \beta\right)=1-\left(1-\exp \left(-e^{x_{i} \beta}\right)\right)=\exp \left(-e^{x_{i} \beta}\right)
$$

Such a distribution is based upon the cumulative distribution function for the Type-I extreme value distribution and is skewed. It was preferred in respect of the standard normal distribution and the logistic distribution due to the nature of data with "extreme" shifts in their values. 


\section{RESULTS AND COMMENTS}

The results of the binary equation are reported in Appendix 3. The quadratic hillclimbing method is used to obtain parameter estimates. This algorithm uses the matrix of analytic second derivatives of the log likelihood in forming iteration updates and in computing the estimated covariance matrix of the coefficients.

A caveat about these results concerns the complexity of coefficient values' interpretation due to the fact that the estimated coefficients of a binary model cannot be interpreted as a marginal effect on the dependent variable. The marginal effect of the explanatory variable $\mathrm{x}_{\mathrm{j}}$ on the conditional probability is given by:

$$
\frac{\partial E\left(y_{i}=1 \mid \mathrm{x}_{\mathrm{i}}, \beta\right)}{\partial x_{i j}}=f\left(x_{i}{ }_{i} \beta\right) \beta_{j}
$$

where $\mathrm{f}(\mathrm{x})=\mathrm{dF}(\mathrm{x}) / \mathrm{dx}$ is the density function corresponding to $\mathrm{F} . \beta_{\mathrm{j}}$ is weighted by a factor that depends on the values of all the regressors in $X$. The direction of the effect of a change in $x_{j}$ depends only on the sign of the $\beta_{j}$ coefficient. Positive values of $\beta_{j}$ imply that increasing $\mathrm{x}_{\mathrm{j}}$ will increase the probability of the response; negative values imply the opposite. In Appendix 3 the coefficient is negative with a level of -0.06 and a $\mathrm{z}$ test of 2.12 suggesting that there is a quite significant statistical connection between the binary and the dummy variables and the sense of such connection is as follows: an increase in the number of involved standards' amendments will tend to lead to an decrease in market volatility. The marginal contribution of the dummy to the conditional probability is depicted in Appendix 4. This contribution fluctuates between $2 \%$ and $20 \%$ and tends to decrease over the entire analysis span.

The second part of Appendix 3 reports the so-called Expectation-Prediction (Classification) Table. This displays the correct and incorrect classification based on a user specified prediction rule and on expected value calculations. Each observation classified as having a predicted probability that lies above or below a cutoff $p=0.5$ value. The bottom of the table window contains prediction results based upon expected value calculations.

It can be noticed that, among the $3 y=1$ observations, the expected number of $y=1$ is 2.44 and among the $17 \mathrm{y}=0$ observations the expected number is 14.48 . These numbers represent roughly a 0.70 percentage point $(2.76$ percent) improvement over the constant probability model.

Such results suggest that the quality of the extreme value model can be considered as satisfactory and, more notably, that the events associated with the involved standards' amendments exert a limited but significant influence on the market dynamics.

\section{CONCLUSIONS AND FURTHER RESEARCH}

This study investigates the reaction of the Eurozone market to the modifications in three relevant IFRSs concerning the financial assets (IFRS 7, IFRS 9, IAS 32 and IAS 39). Such amendments generate adjustments in the investors' expectations in regard to the company's informational environment and influence their judgment of financial information's reliability. Overall, the adoption of IFRS exercise a certain stabilization effect but due to the uncertainty of their implications, such an effect is not necessary a robust one. This output could imply that the investors tend to prefer a higher stability 
in connection to the standards' contents and implementation conditions, in order to avoid the structural changes' costs associated with the modification of their portfolio under the impact of information changes.

Of course, the viability of such a conclusion is affected by the limits of the study. Among them: (1) the too schematic conceptual framework which generally describes the prices' mechanisms influenced by the informational structure but does not really intimately associate the transmission channels with the particularities of financial markets; (2) the reduced set of events / the short time period observations; (3) the limits of the binary equation methodology; (4) the linear relationships considered despite the fact that the study argues against them (5) the econometrics' problems associated with the model parameters robustness and its predictive capacity and so on.

Thus, further research directions should minimally deal with: (1) the construction of an integrated theoretical framework with the inclusion of different features such as the non-linear / co-integration relationships between the financial information and financial assets' valuation in the context of a certain informational architecture; (2) a ex ante analysis of the relative relevance of different standards and a more detailed evaluation of their capacity to meet the investors specific requirements; (3) an extension of the data set inclusive in gathering and incorporating national data.

In spite all these caveats, the main conclusion is that financial information is relevant for capital markets' evolution. More generally, despite the fact that nor the theoretical foundations nor the empirical evidences are conclusive, we argue that the architecture of the informational environment can be seen as one of the key variables in investors' decisions and markets' evolution.

\section{REFERENCES}

Agostino, M., Drago, D. and Silipo D.B. (2008) "International Accounting Standards and Information Efficiency in the European Stock Market" available on-line http://papers.ssrn.com/sol3/ papers.cfm?abstract_id=1093278 accessed on October 25, 2009

Armstrong, C.S., Barth, M.E., Jagolinzer, A.D. and Riedl, E.J. (2008) "Market Reaction to the Adoption of IFRS in Europe", available on-line at http://ssrn.com/abstract=903429 accessed on October 30, 2009

CESR (2009) "Application of Disclosure Requirements Related to Financial Instruments in the 2008 Financial Statements", available on-line at http://www.iasplus.com/europe/ 0910cesrifrscompliance.pdf accessed on February 10, 2010

CFA Institute (2009) "International Financial Reporting Standards (IFRS). Financial Instrument Accounting Survey", available on-line at http://www.cfainstitute.org/ centre/news/surveys/pdf/financial_instrument_accounting_report.pdf accessed on February 26, 2010

Dontoh, A., Radhakrishnan, S. and Ronen, J. (2000) "The Declining Value Relevance of Accounting Information and Non-Information-Based Trading: An Empirical Analysis". New York University Accounting Working Papers, August, available on-line at http://hdl.handle.net/2451/27581 accessed on October 26, 2009

Elliott R. and Jacobsen, P. (1991) "U. S. accounting: A national emergency.". Journal of Accountancy, November: 54-58

Epstein, L.G. and Schneider, M. (2008) "Ambiguity, Information Quality, and Asset Pricing", Journal of Finance, vol. LXIII, no.1, February 
Jenkins E. (1994) "An information highway in need of capital improvements", Journal of Accountancy, 177 (May): 77-82

Papa, V. (2010) "IFRS 9 - A Perspective on Financial Instrument Accounting" available online at http://www.webcpa.com/news/IFRS-9-Perspective-Financial-Instrument-Accou nting-53015-1.html accessed on February, 27, 2010

Ramesh K. and Thiagarajan, R. (1995) "Inter-temporal decline in earnings response coefficients", Working paper of Northwestern University, Evanston, IL.

Riffe, S. and Thompson, R. (1998) "The Relation between Stock Prices and Accounting Information", Review of Accounting Studies, vol. 4, no. 2: 325-351

Sever M. and Boisclaire, R. (1990) "Financial reporting in the 1990s", Journal of Accountancy, vol. 170, no. 5: 36-41

Violi, R. (2004) "Tax Systems, Financial Integration and Efficiency of European Capital Markets", Ente per gli studi monetari, bancari e finanziari Luigi Einaudi, Quaderni di Ricerche, 58 


\section{APPENDICES}

\section{Appendix 1. Statistic by classification for the "close" price of Dow Jones EURO STOXX 50 Index (seasonally adjusted)}

\begin{tabular}{|c|c|c|c|c|c|c|c|c|c|c|}
\hline $\begin{array}{l}\text { CLOSE } \\
\text { seasonally } \\
\text { adjusted) }\end{array}$ & Mean & Median & Max & Min. & $\underset{*}{\text { Quant. }}$ & Sum. & $\begin{array}{l}\text { Std. } \\
\text { Dev. }\end{array}$ & $\begin{array}{c}\text { Skew } \\
\text {. }\end{array}$ & Kurt. & $\begin{array}{c}\text { Obs } \\
.\end{array}$ \\
\hline $\begin{array}{l}{[2000,} \\
2500)\end{array}$ & 2279.42 & 2279.42 & 2366.13 & 2192.71 & 2279.42 & 4558.85 & 122.62 & 0.00 & 1.00 & 2 \\
\hline $\begin{array}{l}{[2500,} \\
3000)\end{array}$ & 2679.24 & 2670.57 & 2856.74 & 2510.40 & 2670.57 & 8037.71 & 173.34 & 0.09 & 1.50 & 3 \\
\hline $\begin{array}{l}{[3000,} \\
3500)\end{array}$ & 3205.29 & 3148.82 & 3473.59 & 3041.19 & 3148.82 & 16026.42 & 166.21 & 0.86 & 2.44 & 5 \\
\hline $\begin{array}{l}{[3500,} \\
4000)\end{array}$ & 3744.90 & 3680.60 & 3897.20 & 3594.78 & 3680.60 & 18724.49 & 133.39 & 0.21 & 1.35 & 5 \\
\hline $\begin{array}{l}{[4000,} \\
4500)\end{array}$ & 4288.30 & 4306.33 & 4469.00 & 4068.48 & 4306.33 & 21441.50 & 164.68 & -0.24 & 1.61 & 5 \\
\hline All & 3439.45 & 3534.18 & 4469.00 & 2192.71 & 3534.18 & 68788.97 & 693.34 & -0.20 & 1.95 & 20 \\
\hline
\end{tabular}

Appendix 2. Key events for IFRS 7, IFRS 9, IAS 32 and IAS 39

\begin{tabular}{|c|c|c|c|}
\hline DATE & EVENT & $\begin{array}{l}\text { QUARTER } \\
\text { CODIFICATION } \\
\text { (NO. OF } \\
\text { EVENTS) }\end{array}$ & $\begin{array}{l}\text { QUARTER } \\
\text { SCORE }\end{array}$ \\
\hline \multirow[t]{3}{*}{1 January 2005} & Effective date of IAS 39 (Revised 2004); & \multirow{3}{*}{$2005 Q 1=3$} & \multirow{3}{*}{3} \\
\hline & Effective date of IAS 32 (Revised 2003); & & \\
\hline & $\begin{array}{l}\text { IFRS } 7 \text { Financial Instruments: Disclosures } \\
\text { issued }\end{array}$ & & \\
\hline 14 April 2005 & $\begin{array}{l}\text { Amendment issued to IAS } 39 \text { for cash flow } \\
\text { hedges of forecast intra-group transactions }\end{array}$ & \multirow{2}{*}{$2005 \mathrm{Q} 2=2$} & \multirow[t]{2}{*}{5} \\
\hline 15 June 2005 & Amendment to IAS 39 for fair value option & & \\
\hline $\begin{array}{l}18 \text { August } \\
2005\end{array}$ & $\begin{array}{l}\text { Amendment to IAS } 39 \text { for financial } \\
\text { guarantee contracts }\end{array}$ & \multirow[b]{2}{*}{$2005 \mathrm{Q} 3=2$} & \multirow[b]{2}{*}{7} \\
\hline $\begin{array}{l}18 \text { August } \\
2005\end{array}$ & $\begin{array}{l}\text { Disclosure provisions of IAS } 32 \text { are } \\
\text { replaced by IFRS } 7 \text { Financial Instruments: } \\
\text { Disclosures }\end{array}$ & & \\
\hline 22 June 2006 & $\begin{array}{l}\text { Exposure Draft of proposed amendments } \\
\text { relating to Puttable Instruments and } \\
\text { Obligations Arising on Liquidation }\end{array}$ & 2006Q2=1 & 8 \\
\hline 1 January 2007 & Effective date of IFRS 7 & 2007Q1=1 & 9 \\
\hline $\begin{array}{l}6 \text { September } \\
2007\end{array}$ & $\begin{array}{l}\text { Proposed amendment to IAS } 39 \text { for } \\
\text { exposures qualifying for hedge accounting }\end{array}$ & 2007Q3=1 & 10 \\
\hline $\begin{array}{l}14 \text { February } \\
2008\end{array}$ & $\begin{array}{l}\text { IAS } 32 \text { amended for Puttable Instruments } \\
\text { and Obligations Arising on Liquidation }\end{array}$ & 2008Q1=1 & 11 \\
\hline 22 May 2008 & $\begin{array}{l}\text { IAS } 39 \text { amended for 'Annual Improvements } \\
\text { to IFRSs } 2007\end{array}$ & 2008Q2=1 & 12 \\
\hline 30 July 2008 & $\begin{array}{l}\text { Amendment to IAS } 39 \text { for eligible hedged } \\
\text { items }\end{array}$ & 2008Q3=1 & 13 \\
\hline $\begin{array}{l}13 \text { October } \\
2008\end{array}$ & $\begin{array}{l}\text { Amendment to IFRS } 7 \text { for disclosures } \\
\text { relating to reclassifications of financial } \\
\text { assets }\end{array}$ & \multirow[b]{2}{*}{$2008 Q 4=4$} & \multirow[t]{2}{*}{17} \\
\hline $\begin{array}{l}13 \text { October } \\
2008\end{array}$ & $\begin{array}{l}\text { Amendment to IAS } 39 \text { for reclassifications } \\
\text { of financial assets }\end{array}$ & & \\
\hline
\end{tabular}




\begin{tabular}{|c|c|c|c|}
\hline $\begin{array}{l}22 \text { December } \\
2008\end{array}$ & $\begin{array}{l}\text { Proposed amendment to IAS } 39 \text { for } \\
\text { Embedded Derivatives Assessment }\end{array}$ & & \\
\hline $\begin{array}{l}23 \text { December } \\
2008\end{array}$ & $\begin{array}{l}\text { Exposure Draft of proposed amendments to } \\
\text { IFRS } 7 \text { issued }\end{array}$ & & \\
\hline 1 January 2009 & $\begin{array}{l}\text { IAS 32: Effective date of amendments for } \\
\text { puttable instruments and obligations arising } \\
\text { on liquidation }\end{array}$ & \multirow{6}{*}{$2009 \mathrm{Q} 1=6$} & \multirow{6}{*}{23} \\
\hline 1 January 2009 & $\begin{array}{l}\text { IFRS 7: Retroactive effective date of the: } \\
\text { March } 2009 \text { enhanced fair value disclosure } \\
\text { amendments; }\end{array}$ & & \\
\hline 1 January 2009 & $\begin{array}{l}\text { IFRS 7: Effective date of the: scope } \\
\text { exemption for puttable instruments } \\
\text { classified as equity; }\end{array}$ & & \\
\hline 1 January 2009 & $\begin{array}{l}\text { IFRS 7: Effective date of the: exemption } \\
\text { from presenting additional IAS 27, IAS } 28 \\
\text { and IAS31 disclosures amendment }\end{array}$ & & \\
\hline 5 March 2009 & $\begin{array}{l}\text { Amendment to IFRS } 7 \text { on enhancing } \\
\text { disclosures about fair value and liquidity } \\
\text { risk }\end{array}$ & & \\
\hline 12 March 2009 & $\begin{array}{l}\text { Amendment to IAS } 39 \text { for embedded } \\
\text { derivatives on reclassifications of financial } \\
\text { assets }\end{array}$ & & \\
\hline 16 April 2009 & $\begin{array}{l}\text { IAS } 39 \text { amended for Annual Improvements } \\
\text { to IFRSs } 2009\end{array}$ & $2009 Q 2=1$ & 24 \\
\hline 1 July 2009 & $\begin{array}{l}\text { IFRS 7: Effective date of the January } 2008 \\
\text { IFRS } 3 \text { consequential amendment }\end{array}$ & \multirow{4}{*}{$2009 \mathrm{Q} 3=4$} & \multirow{4}{*}{28} \\
\hline 1 July 2009 & $\begin{array}{l}\text { IAS 39: Effective date of the July } 2008 \text { and } \\
\text { March } 2009 \text { amendments }\end{array}$ & & \\
\hline 14 July 2009 & $\begin{array}{l}\text { IASB issues exposure draft Financial } \\
\text { Instruments: Classification and } \\
\text { Measurement }\end{array}$ & & \\
\hline 6 August 2009 & $\begin{array}{l}\text { Exposure Draft Classification of Rights } \\
\text { Issues proposing to amend IAS } 32\end{array}$ & & \\
\hline 8 October 2009 & $\begin{array}{l}\text { Amendment to IAS } 32 \text { about Classification } \\
\text { of Rights Issues }\end{array}$ & \multirow{4}{*}{$2009 Q 4=4$} & \multirow{4}{*}{32} \\
\hline $\begin{array}{l}5 \text { November } \\
2009\end{array}$ & $\begin{array}{l}\text { Proposed amendment to IAS } 39 \text { for } \\
\text { impairment of financial assets measured at } \\
\text { amortised cost }\end{array}$ & & \\
\hline $\begin{array}{l}12 \text { November } \\
2009\end{array}$ & $\begin{array}{l}\text { IASB issues IFRS } 9 \text { Financial Instruments, } \\
\text { with early adoption permitted starting in } \\
2009 \text {. }\end{array}$ & & \\
\hline $\begin{array}{l}12 \text { November } \\
2009\end{array}$ & $\begin{array}{l}\text { Classification and measurement provisions } \\
\text { of IAS } 39 \text { replaced by IFRS } 9\end{array}$ & & \\
\hline
\end{tabular}

\section{Appendix 3. The binary (extreme value) regression and the Expectation-} Prediction Table Method: ML - Binary Extreme Value (Quadratic hill climbing)

\begin{tabular}{||l|l|l|l|l||}
\hline \multicolumn{1}{|c|}{ Variable } & Coefficient & Std. Error & $z$-Statistic & Prob. \\
\hline \multicolumn{1}{|c|}{ DUMMY } & -0.06 & 0.03 & -2.12 & 0.03 \\
\hline & & & & \\
\hline Mean dependent variable & 0.15 & \multicolumn{2}{|c||}{ S.D. dependent variable } & 0.37 \\
\hline S.E. of regression & 0.36 & Akaike info criterion & 0.89 \\
\hline Sum squared residuals & 2.50 & Schwarz criterion & 0.94 \\
\hline Log likelihood & -7.89 & \multicolumn{2}{|l|}{ Hannan-Quinn criterion } & 0.90 \\
\hline Avg. log likelihood & -0.39 & \multicolumn{3}{l}{} \\
\hline
\end{tabular}




\begin{tabular}{||c|r|r|r|r|r|r||}
\hline & \multicolumn{3}{|c|}{ Estimated Equation } & \multicolumn{3}{|c||}{ Constant Probability } \\
\hline & Dep=0 & Dep $=1$ & Total & Dep $=0$ & Dep $=1$ & Total \\
\hline $\mathrm{E}($ Dependent $=0)$ & 14.48 & 2.44 & 16.92 & 14.45 & 2.55 & 17 \\
\hline $\mathrm{E}($ Dependent $=1)$ & 2.52 & 0.56 & 3.08 & 2.55 & 0.45 & 3 \\
\hline Total & 17 & 3 & 20 & 17.00 & 3.00 & 20 \\
\hline Correct & 14.48 & 0.56 & 15.04 & 14.45 & 0.45 & 14.90 \\
\hline$\%$ Correct & 85.19 & 18.62 & 75.20 & 85.00 & 15.00 & 74.50 \\
\hline$\%$ Incorrect & 14.81 & 81.38 & 24.80 & 15.00 & 85.00 & 25.50 \\
\hline Total Gain* & 0.19 & 3.62 & 0.70 & & & \\
\hline Percent Gain** & 1.26 & 4.25 & 2.76 & & & \\
\hline$*$ Change in "\% Correct" from default (constant probability) specification \\
\hline **Percent of incorrect (default) prediction corrected by equation \\
\hline
\end{tabular}

\section{Appendix 4. The marginal contribution of the dummy variable to the conditional probability}

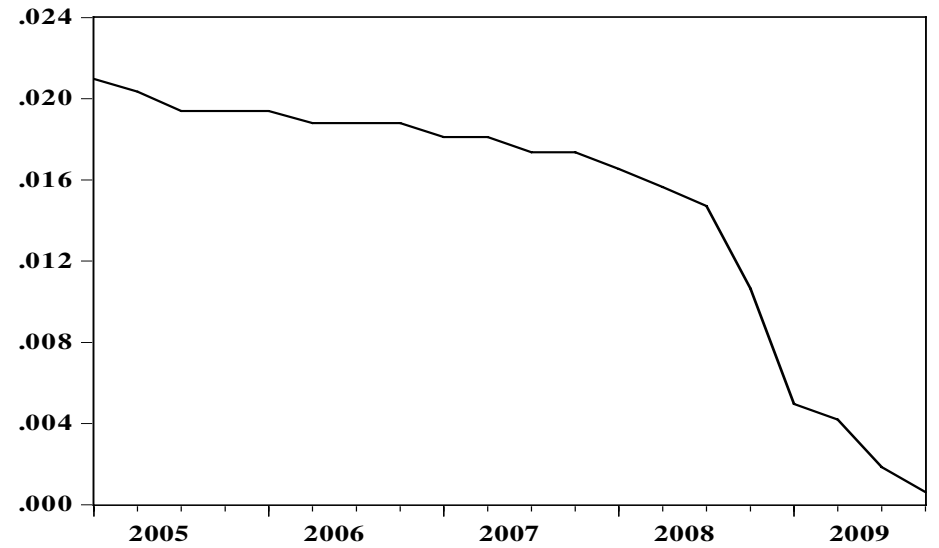

i Available on-line at http://www.iasplus.com/resource/0904g20communique2.pdf accessed on December 13, 2009

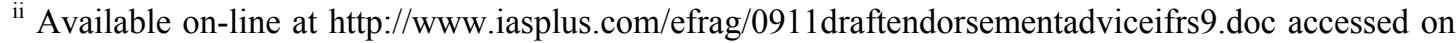
December 13, 2009

iii Available on-line at http://www.iasplus.com/restruct/euro2009.htm, accessed on January 30, 2010

iv Available on-line at http://www.iasplus.com/europe/0911 responsefrommccreevy.pdf accessed on December 15, 2009 